\title{
Serum Cholesterol-lowering Effect of Fermented Milk with Streptococcus thermophilus TMC 1543
}

\author{
Manabu KAWASE, Hideo HASHIMOTO, Masataka HOSODA, Hirotsugu MORITA \\ and Akiyoshi HOSONO ${ }^{1}$ \\ Technical Research Laboratory, Takanashi Milk Products Co., Ltd., Asahi-ku, \\ Yokohama-shi 241-0023, Japan \\ ' Faculty of Agriculture, Shinshu University, Minamiminowa-mura \\ Nagano-ken 399-4598, Japan
}

(Received August 10, 2000 ; Accepted October 18, 2000)

\begin{abstract}
The serum cholesterol lowering action of fermented milk with Streptococcus thermophilus TMC 1543 ( 1543 FM), the mechanism behind the cholestcrol lowering activity and the active factor in animal experiments were investigated using rats. The serum total cholesterol level of the group fed 1543 FM was significantly lower than that of the control group $(\mathbf{P}<0.05)$. However, there were no serum cholesterol lowering activities in fermented milks with the other two lactic acid bacteria. The serum total cholesterol concentration of the group fed low-molecular-weight fraction (LMF) from 1543 FM was significantly lower than that of the control group $(\mathbf{P}<0.05)$. High-molecular-weight fraction (HMF) also tended to lower serum cholesterol level in the present animal study. The amounts of excretion of both total bile acid and neutral sterol in feces of the 1543 FM group increased significantly in comparison with the control group $(\mathbf{P}<0.05)$. These results suggest that the mechanism behind serum cholesterol lowering activity of $1543 \mathrm{FM}$ would be attributable to the promotion of excretion of bile acid and neutral steroid through feces, and probably the low-molecular material in LMF.

Animal Science Journal 72 (1) : 54-62, 2001
\end{abstract}

Key words : Cholesterol, Streptococcus thermophilus, Fermented milk, Bile acid, Rat

Mann and Spoerry ${ }^{14}$ first reported serum cholesterol-lowering activity of fermented milk. Afterwards, the potential cholesterol-lowering activity of fermented milk on humans have been reported, and some studies have observed significant reduction in serum cholesterol level ${ }^{1,2,9,11)}$. It has also been reported that fermented milk decrease serum cholesterol level in rats ${ }^{11,18,20,26)}$. Although there are many reports on the mechanism behind cholesterol-lowering activity of fermented milk in vitro and in vivo, there are only a few reports on the mechanism and active factor behind fermented milk. Rao et al. ${ }^{20)}$ reported that the milk fermented by Streptococcus thermophilus and methanol solubles from the fermented milk decreased plasma cholesterol levels in rats and that the methanol solubles inhibited hepatic cholesterogenesis in vitro. However, the cholesterol lowering factor has been not identified yet. Nakajima et al. ${ }^{17,18)}$ reported that milk fermented by Lactococcus lactis subsp. cremoris SBT 0495 isolated from viili (Viili is Finnish traditional fermented milk) has cholesterol lowering activity and that the active factor might be slime materials, which contained phosphopolysaccharide produced by the lactic acid bacteria. Although it is difficult to characterize the active factors from a fermented milk with serum cholesterol lowering activity, the characterization is very important for development of functional foods (medical foods).

Our previous report showed that a fermented milk containing whey protein concentrate (WPC) with

Corresponding: Akiyoshi HOSONO (fax : +81 (0) 265-77-1428, e-mail : ahosono@gipmc.shinshu-u.ac.jp) 


\section{Cholesterol-lowering Effect of Fermented Milk}

Table 1. Lactic acid bacterial numbers and acidities (lactic acid) in fermented milks

\begin{tabular}{rlcc}
\hline Lactic acid bacteria & $\begin{array}{c}\text { Lactic acid } \\
\text { bacterial number } \\
(\log \mathrm{cfu} / \mathrm{m} l)\end{array}$ & $\begin{array}{c}\text { Acidity } \\
\text { (Lactic acid) }\end{array}$ \\
\hline $109 \mathrm{FM}^{13}$ & L. casei TMC 109 & $1.4 \times 10^{9}$ & 1.34 \\
$114 \mathrm{FM}$ & L. casei TMC 114 & $1.0 \times 10^{9}$ & 1.12 \\
$1543 \mathrm{FM}$ & S. thermophilus TMC 1543 & $1.0 \times 10^{7}$ & 1.24 \\
\hline
\end{tabular}

1) $109 \mathrm{FM}=$ Fermented milk with $L$. casei $\mathrm{TMC} 109,114 \mathrm{FM}=$ Fermented milk with L. casei TMC 114, 1543 FM=Fermented milk with S. thermophilus TMC 1543.

both S. thermophilus TMC1543 and Lactobacillus casei TMC 0409 lowered the serum total cholesterol level in rat induced by high-cholesterol diet ${ }^{11}$. Furthermore, the fermented milk lowcred the serum triglyceride level and the atherogenic index in healthy men $^{11 \prime}$. However, it is necessary to investigate serum cholesterol lowering activity of fermented milk (not contained WPC) with S. thermophilus TMC 1543 in animals.

The objectives of this study were to investigate serum cholesterol lowering action of fermented milk with S. thermophilus TMC 1543 (1543 FM), the mechanism behind the cholesterol lowering activity and the active factor in animals using rats.

\section{Materials and Methods}

\section{Bacterial strains}

L. casei TMC 109 and S. thermophilus TMC 1543 were isolated from fermented milk products. L. casei TMC 114 was isolated from human feces. All bacterial strains were maintained in Technical Research Laboratory, Takanashi Milk Products. Co., Ltd.

\section{Fermented milk}

L. casei TMC 109, L. casei TMC 114 and S. thermophilus TMC 1543 were used as starters of fermented milk. The composition of pasteurized milk base was $10.5 \%$ skim milk powder, $0.35 \%$ soybean peptide, $0.87 \%$ sucrose, $0.87 \%$ fructose and $87.4 \%$ water. Three fermented milks were made by fermenting pasteurized milk base with these lactic acid bacteria. The lactic acid bacterial numbers and acidity (lactic acid) in the fermented milks are shown in Table 1. All fermented milks were lyophilized for experimental diets. The lyophilized fermented milks per $100 \mathrm{~g}$ of dry weight contained $30.0-32.6 \mathrm{~g}$ of protein, $0.5-0.8 \mathrm{~g}$ of fat, 55.7-57.4 g of sugar, 6.7-7.1 g of ash, and 4.2$4.8 \mathrm{~g}$ of water. Skim milk per $100 \mathrm{~g}$ dry weight for the control diet contained $33.9 \mathrm{~g}$ of protein, $0.7 \mathrm{~g}$ of fat, $53.2 \mathrm{~g}$ of sugar, $7.9 \mathrm{~g}$ of ash, and $4.1 \mathrm{~g}$ of water.

\section{Preparation of fractions from fermented milk}

Fermented milk with $S$. thermophilus TMC 1543 was centrifuged at $10,000 \times \mathrm{g}$ for $10 \mathrm{~min}$, and the supernatant and precipitate were defined as whey fraction and casein fraction, respectively. Whey fraction was heated at $65^{\circ} \mathrm{C}$ for $30 \mathrm{~min}$, and cooled, and was ultrafiltrated by a ceramic membrane filter (MW cut-off 10,000, Cefilt; Nihon Gaishi corp., Japan), and then the low-molecular-weight fraction (LMF) from the filtrate was obtained after freeze-drying. Also, whey fraction was heated at $65^{\circ} \mathrm{C}$ for $30 \mathrm{~min}$, and cooled, and was hydrolyzed by addition of $0.07 \%$ acidic protease (Orientase $20 \mathrm{~A}$, from Aspergillus nizer ; Hankyu-Bio-Industry, Osaka, Japan) at $50^{\circ} \mathrm{C}$ for $17 \mathrm{~h}$. After that, the digest was heated at $80{ }^{\circ} \mathrm{C}$ for $30 \mathrm{~min}$. An $80 \mathrm{l}$ distilled water was added to $20 \mathrm{l}$ of the digest, and the whole solution was concentrated to $20 l$ by a ceramic membrane filter (MW cut-off 10,000, Cefilt ; Nihon Gaishi corp., Japan), and then the high-molecular-weight fraction (HMF) from the concentrate was obtained after freeze-drying. The weight of each fraction was measured. The yields and chemical compositions of each fraction preparated from $1543 \mathrm{FM}$ are shown in Table 2.

\section{Animals}

Male Sprague-Dawley rats, 4 week old, were purchased from Clea Japan, Inc. Tokyo, Japan. All rats were initially given a standard diet (MF, Oriental 
KAWASE, HASHIMOTO, HOSODA, MORITA and HOSONO

Table 2. Yield of each fraction from fermented milk with $S$. thermophilus TMC 1543

\begin{tabular}{|c|c|c|c|c|c|c|c|}
\hline & \multirow{2}{*}{$\begin{array}{c}\text { Total } \\
\text { contents } \\
(\mathrm{g})\end{array}$} & \multirow{2}{*}{$\begin{array}{l}\text { Yield } \\
(\%)\end{array}$} & \multicolumn{5}{|c|}{ Sample composition ( $\mathrm{g} / 100 \mathrm{~g}$ of dried sample) } \\
\hline & & & Protein & Lipid & Sugar & Ash & Water \\
\hline $1543 \mathrm{FM}^{11}$ & 2920 & 100 & 32.6 & 0.8 & 55.7 & 6.7 & 4.2 \\
\hline Casein fraction & 1138 & 39.0 & 60.0 & 0.0 & 31.0 & 4.0 & 5.0 \\
\hline Whey fraction & 1766 & 60.5 & 6.6 & 1.6 & 76.8 & 8.6 & 6.4 \\
\hline LMF & 230 & 7.9 & 3.7 & 0.0 & 74.6 & 11.6 & 10.1 \\
\hline HMF & 320 & 11 & 3.0 & 1.8 & 74.2 & 7.2 & 9.8 \\
\hline
\end{tabular}

1) $1543 \mathrm{FM}=$ Fermented milk with $S$. thermophilus $\mathrm{TMC} 1543, \mathrm{LMF}=$ low-molecular-weight fraction, $\mathrm{HMF}=$ high-molecular-weight fraction.

Table 3. Composition of experimental diets (Animal experiment 1)

\begin{tabular}{|c|c|c|}
\hline & \multicolumn{2}{|c|}{ Diets $(g / 100 g)$} \\
\hline & Control group & $\begin{array}{l}\text { Experimental } \\
\text { dict group }\end{array}$ \\
\hline Casein & 15.0 & 15.0 \\
\hline Skim milk & 20.0 & 0.0 \\
\hline Fermented milk & 0.0 & 20.0 \\
\hline Lard & 9.0 & 9.0 \\
\hline Corn oil & 1.0 & 1.0 \\
\hline Vitamin mixture $^{1}$ & 0.85 & 0.85 \\
\hline Mineral mixture ${ }^{21}$ & 4.0 & 4.0 \\
\hline Choline chloride & 0.15 & 0.15 \\
\hline Cellulose powder & 2.0 & 2.0 \\
\hline Cholesterol & 0.5 & 0.5 \\
\hline Sodium cholate & 0.125 & 0.125 \\
\hline Sucrose & 47.375 & 47.375 \\
\hline Total & 100.0 & 100.0 \\
\hline
\end{tabular}

1.2) ; AIN-76.

Yeast Co., Ltd., Tokyo, Japan) for 7 days. The rats were divided on the basis of their mean body weight and housed in an air-conditioned room at $25 \pm 2{ }^{\circ} \mathrm{C}$ with $55 \pm 5 \%$ humidity on a $12 \mathrm{~h}$ light-dark cycle. After 7 days, each group was given the experimental diets for 14 days shown in the following paragraphs and allowed tap water ad libitum. The overnight (15 h) fasted rats were anesthetized by intraperitoneal injection of sodium pentobarbital $(40 \mathrm{mg} / \mathrm{kg}$ body weight, Nenbutal ; Abbott Laboratories, North Chicago, IL, USA) at 14 day for serum lipid analysis, and
Table 4. Composition of experimental diets (Animal experiment 2)

\begin{tabular}{lcc}
\hline \hline & \multicolumn{2}{c}{ Diets $(\mathrm{g} / 100 \mathrm{~g})$} \\
\cline { 2 - 3 } & Control group & $\begin{array}{c}\text { Experimental } \\
\text { diet group }\end{array}$ \\
\hline Casein & 15.0 & 15.0 \\
Skim milk & 20.0 & 20.0 \\
Lard & 9.0 & 9.0 \\
Corn oil & 1.0 & 1.0 \\
Vitamin mixture ${ }^{1,}$ & 0.85 & 0.85 \\
Mineral mixture & 4.0 & 4.0 \\
Choline chloride & 0.15 & 0.15 \\
Cellulose powder & 2.0 & 2.0 \\
Cholesterol & 0.5 & 0.5 \\
Sodium cholate & 0.125 & 0.125 \\
Test sample & 0.0 & 5.0 \\
Sucrose & 47.375 & 42.375 \\
Total & 100.0 & 100.0 \\
\hline
\end{tabular}

blood samples were taken from the abdominal aorta. All experiments using animals were performed in accordance with the Guideline for the Use and Care of Laboratory Animals (The Prime Minister's Office announcement No. 6, Japan, 1980).

\section{Animal experiment 1}

Rats were divided into three groups of seven on the basis of their mean body weight. Each group was given experimental diets for 14 days shown in Table 3 .

Animal experiment 2

The rats were divided five groups of seven rats on 
the basis of their mean body weight. They were allowed experimental diets with paired feeding for 14 days shown in Table 4.

\section{Animal experiment 3}

The rats were divided into two groups of twelve on the basis of their mean body weight. Each group was given either control diet or experimental diet of 1543 FM for 14 days shown in Table 3. After blood collection, livers were excised, and were stored in a similar method as above. All feces during 14 days of test period were collected, and weights were measured. The feces were freeze-dried, were powdered by a mixer.

\section{Serum lipid analysis}

Serum total cholesterol, triglyceride, high density lipoprotein (HDL) cholesterol, and phospholipid were measured using Cholesterol E Test Waco, Triglyceride $G$ Test Waco, HDL-cholesterol Test Waco and Phospholipid C Test Waco (Wako Pure Chemical Industries, Ltd., Osaka, Japan), respectively.

\section{Liver lipid analysis}

Liver lipids were extracted by the modified method of Kovacs et al. ${ }^{12}$. One gram of homogenized aliquot was saponified in a tightly capped tube containing $10 \mathrm{ml}$ of $99.5 \%$ ethanol and $5 \mathrm{ml}$ of $50 \% \mathrm{KOH}$ at $80^{\circ} \mathrm{C}$ for $1 \mathrm{~h}$. After cooling, $10 \mathrm{~m} /$ distilled water was added and unsaponifiables were extracted 3 times with hexane (each $15 \mathrm{ml}$ ). The combined extracts were dried under nitrogen gas. Lipids in the dried residue were analyzed according to Danno et al. ${ }^{5)}$. Thus, the dried residues were dissolved in $10 \mathrm{~m} l$ hexane, $1 \mathrm{ml}$ of the aliquots were dried and were redissolved in $600 \mu \mathrm{l}$ tert-butyl alcohol and $400 \mu l$ Triton X-100/methanol (1:1) mixture. These redissolved materials were mixed, and Cholesterol and Triglyceride in the mixtures were measured using Cholesterol E Test Waco and Triglyceride G Test Waco (Wako Pure Chemical Industries, Ltd.), respectively.

\section{Fecal steroid analysis}

The analyses of total bile acid in feces were examined by the method of Sautier et al. ${ }^{22)}$. Thus, $0.1 \mathrm{~g}$ freeze-dried fecal samples were suspended in 2.5 $\mathrm{m} l$ hot ethanol in the test tube with the screw cap and extracted at $80^{\circ} \mathrm{C}$ for $1 \mathrm{~h}$. The supernatant was collected by centrifugation $(1,690 \mathrm{~g}, 15 \mathrm{~min})$. This ex- traction procedure was conducted three times, and the supernatants were evaporated under nitrogen gas at $50^{\circ} \mathrm{C}$. The residues were redissolved in $8.0 \mathrm{~m} l$ ethanol. Fecal total bile acid was measured by commercial test kit (Enzabile II, Daiichi Kagaku Yakuhin, Tokyo, Japan)

The extraction of cholesterol and coprostanol from feces was conducted by the modified method for liver lipid analysis. A $0.1 \mathrm{~g}$ of homogenized aliquot was saponified in a tightly capped tube containing $4 \mathrm{ml}$ of $99.5 \%$ ethanol and $1 \mathrm{ml}$ of $50 \% \mathrm{KOH}$ at $80^{\circ} \mathrm{C}$ for $1 \mathrm{~h}$. After the saponification, the solution in tubes were added with $1 \mathrm{ml} 5 \alpha$-cholestan solution $(25 \mathrm{mg} / 100 \mathrm{ml}$ ) as internal standard. The solution in tubes were added with $1.0 \mathrm{~m} l$ distilled water and unsaponifiables were extracted 3 times with hexane (each $2.5 \mathrm{~m} l$ ). The combined extracts were dried under nitrogen gas at $50^{\circ} \mathrm{C}$. The residues were redissolved in $4.0 \mathrm{ml}$ hexane and were filtered. Cholesterol and coprostanol in feces were measured by gas liquid chromatography (GLC). GLC analysis was performed on GLC (GC-353 B, GL science, Tokyo, Japan) with FID detector. The column was used capillary column (DV-17, $0.25 \times 30 \mathrm{~m}$, film thickness $0.15 \mu \mathrm{m}$, J \& W Scientific, CA, USA). The conditions of $\mathrm{GLC}$ were column temperature : $260^{\circ} \mathrm{C}$, injection temperature : $250^{\circ} \mathrm{C}$, detector $: 300^{\circ} \mathrm{C}$, carrier gas : He $(1 \mathrm{ml} / \mathrm{min})$, make up gas : $\mathrm{N}_{2}(30 \mathrm{ml} / \mathrm{min})$ and split ratio : $1 / 50$.

\section{Statistical analysis}

Statistical significance of the differences between control and diet groups in animal experiments was calculated using unpaired Student's $t$-test with Microsoft Excel, Version 5.0.

\section{Results}

\section{Animal experiment 1}

Table 5 shows the food intake, body weight, serum lipids and liver lipids in rats. There were no significant differences in food intake between the control group and the three experimental groups. The body weight and the body weight gain for the group (109 FM) fed fermented milk with $L$. casei TMC 109 were significantly lower than those of the control group, respectively $(\mathrm{P}<0.05)$. The serum total cholesterol 
Table 5. Food intake, body weight, serum lipid concentrations in Rat (Animal experiment 1)

\begin{tabular}{|c|c|c|c|c|}
\hline & \multicolumn{4}{|c|}{ Groups $^{2)}$} \\
\hline & Control & 109 FM & $114 \mathrm{FM}$ & $1543 \mathrm{FM}$ \\
\hline Food intake $(\mathrm{g} / 14$ days $)$ & $232.4 \pm 4.7^{1 !}$ & $230.4 \pm 5.5$ & $238.6 \pm 6.6$ & $229.8 \pm 7.6$ \\
\hline Body weight at 0 day (g) & $143.7 \pm 2.2$ & $143.1 \pm 1.6$ & $140.7 \pm 1.4$ & $143.0 \pm 1.4$ \\
\hline Body weight at 14 day $(\mathrm{g})$ & $240.0 \pm 3.7$ & $229.0 \pm 2.2^{*}$ & $229.1 \pm 4.3$ & $231.6 \pm 4.6$ \\
\hline Body weight gain ( $g / 14$ days) & $96.3 \pm 2.8$ & $85.9 \pm 2.8^{*}$ & $88.4 \pm 4.1$ & $88.6 \pm 3.4$ \\
\hline \multicolumn{5}{|l|}{ Serum lipids } \\
\hline Total cholesterol $(\mathrm{mg} / \mathrm{d} l)$ & $175.0 \pm 12.5$ & $152.3 \pm 12.2$ & $169.3 \pm 18.6$ & $128.1 \pm 8.8^{* *}$ \\
\hline Triglyceride $(\mathrm{mg} / \mathrm{d} l)$ & $88.5 \pm 11.7$ & $101.5 \pm 13.7$ & $104.2 \pm 14.5$ & $95.9 \pm 8.0$ \\
\hline HDL-cholesterol $(\mathrm{mg} / \mathrm{d} l)$ & $15.2 \pm 1.8$ & $15.0 \pm 1.0$ & $18.5 \pm 2.1$ & $16.1 \pm 8.1$ \\
\hline Phospholipid (mg/dl) & $121.2 \pm 3.3$ & $110.7 \pm 6.7$ & $117.2 \pm 7.9$ & $103.8 \pm 4.7 *$ \\
\hline
\end{tabular}

"Values are means \pm SEM $(n=7)$.

${ }^{21} 109 \mathrm{FM}=$-Fermented milk with $L$. casei $\mathrm{TMC} 109,114 \mathrm{FM}=$ Fermented milk with $L$. casei TMC 114, $1543 \mathrm{FM}$ $=$ Fermented milk with $S$. thermophilus TMC 1543 .

Asterisks are significantly different from control $\left({ }^{*} \mathbf{P}<0.05,{ }^{*} * \mathrm{P}<0.01\right)$.

Table 6. Food intake, body weight, serum lipid concentrations in Rat (Animal experiment 2)

\begin{tabular}{|c|c|c|c|c|c|}
\hline & \multicolumn{5}{|c|}{ Groups } \\
\hline & Control & Casein fraction & Whey fraction & $\mathrm{LMF}^{21}$ & $\mathrm{HMF}^{2 !}$ \\
\hline Food intake ( $\mathrm{g} / 14$ days $)$ & $222.5 \pm 8.0^{11}$ & $233.1 \pm 8.6$ & $235.2 \pm 6.5$ & $238.7 \pm 5.8$ & $230.3 \pm 6.1$ \\
\hline Body weight at 0 day (g) & $144.3 \pm 1.5$ & $143.0 \pm 2.3$ & $112.3 \pm 1.7$ & $141.4 \pm 1.6$ & $144.1 \pm 1.9$ \\
\hline Body weight at 14 day $(\mathrm{g})$ & $233.4 \pm 5.5$ & $210.3 \pm 5.9$ & $236.3 \pm 4.1$ & $243.1 \pm 4.7$ & $236.9 \pm 4.9$ \\
\hline Body weight gain ( $g / 14$ days) & $89.1 \pm 4.1$ & $97.3 \pm 3.7$ & $91.0 \pm 3.2$ & $98.7 \pm 4.0$ & $92.7 \pm 3.5$ \\
\hline \multicolumn{6}{|l|}{ Serum lipids } \\
\hline Total cholesterol $(\mathrm{mg} / \mathrm{d} l)$ & $222.6 \pm 22.3$ & $179.9 \pm 16.5$ & $176.1 \pm 18.8$ & $143.5 \pm 16.1 *$ & $167.4 \pm 14.4$ \\
\hline HDL-cholesterol $(\mathrm{mg} / \mathrm{d} l)$ & $20.1 \pm 1.7$ & $19.6 \pm 1.5$ & $20.4 \pm 1.8$ & $19.4 \pm 0.9$ & $17.8 \pm 1.6$ \\
\hline Triglyceride $(\mathrm{mg} / \mathrm{d} l)$ & $130.5 \pm 16.9$ & $101.8 \pm 18.9$ & $91.2 \pm 17.7$ & $67.2 \pm 10.8 *$ & $83.1 \pm 8.3^{*}$ \\
\hline Phospholipid (mg/dl) & $144.7 \pm 12.0$ & $126.8 \pm 8.4$ & $122.4 \pm 7.8$ & $113.4 \pm 2.6^{*}$ & $117.5 \pm 4.0^{*}$ \\
\hline
\end{tabular}

1) Values are means \pm SEM $(n=7)$.

2) $\mathrm{LMF}=$ low-molecular-weight fraction, $\mathrm{HMF}=$ high-molecular-weight fraction.

Asterisks are significantly different from control $\left({ }^{*} \mathbf{P}<0.05,{ }^{* *} \mathrm{P}<0.01\right)$.

concentration for the group fed $1543 \mathrm{FM}$ was significantly lower than that of the control group $(\mathrm{P}<0.05)$. However, the serum triglyceride concentration and HDL-cholesterol concentration did not show statistical significance between the control group and the other three groups.

\section{Animal experiment 2}

Table 6 shows the food intake, body weight and Anim. Sci. J. 72 (1) : 54-62, 2001 serum lipids in rats. There were no significant differences in both body weight gain and food intake between the control group and the four experimental groups. The serum total cholesterol concentration of the LMF group was significantly lower than that of the control group $(\mathbf{P}<0.05)$. The High-molecularweight fraction (HMF) also tended to have low serum cholesterol level $(P=0.08)$. The serum triglyceride 
Table 7. Food intake, body weight, serum lipids, liver lipids and fecal steroids in Rats (Animal experiment 3)

\begin{tabular}{|c|c|c|}
\hline & Control & $1543 \mathrm{FM}^{2}$ \\
\hline Food intake ( $g / 14$ days) & $243.3 \pm 6.6^{11}$ & $256.8 \pm 3.8$ \\
\hline Body weight at 0 day (g) & $144.5 \pm 1.9$ & $145.1 \pm 1.3$ \\
\hline Body weight at 14 day (g) & $228.8 \pm 5.5$ & $232.6 \pm 2.3$ \\
\hline Body weight gain (g/14 days) & $84.3 \pm 4.4$ & $87.5 \pm 2.4$ \\
\hline \multicolumn{3}{|l|}{ Serum lipids } \\
\hline Total cholesterol $(\mathrm{mg} / \mathrm{d} l)$ & $186.1 \pm 15.9$ & $130.9 \pm 13.3^{*}$ \\
\hline Triglyceride $(\mathrm{mg} / \mathrm{d} l)$ & $98.9+12.9$ & $77.2 \pm 6.8$ \\
\hline HDL-cholesterol $(\mathrm{mg} / \mathrm{d} l)$ & $20.7 \pm 0.7$ & $21.3 \pm 0.9$ \\
\hline Phospholipid (mg/dl) & $124.6 \pm 6.3$ & $106.2 \pm 4.7 *$ \\
\hline Liver weight ( $\mathrm{g}$ wet) & $10.0 \pm 0.3$ & $10.2 \pm 0.2$ \\
\hline Cholesterol ( $\mathrm{mg} / \mathrm{g}$ of Liver) & $58.8 \pm 0.8$ & $59.8 \pm 1.4$ \\
\hline Triglyceride ( $\mathrm{mg} / \mathrm{g}$ of Liver) & $15.5 \pm 1.7$ & $19.9 \pm 1.4$ \\
\hline Fecal weight (g wet/14 days) & $25.8+1.2$ & $24.1 \pm 0.9$ \\
\hline \multicolumn{3}{|l|}{ Fecal sterol excretion } \\
\hline Cholesterol (mg/14 days) & $321.2+14.4$ & $343.7 \pm 13.3$ \\
\hline Coprostanol (mg/14 days) & $36.3 \pm 2.2$ & $51.7 \pm 3.5 * *$ \\
\hline Neutral sterol (mg/14 days) & $357.4 \pm 15.1$ & $395.4 \pm 11.8^{*}$ \\
\hline Total bile acid $(\mu \mathrm{mol} / 14$ days $)$ & $337.3 \pm 23.1$ & $390.3 \pm 13.4^{*}$ \\
\hline
\end{tabular}

1) Values are means $\pm \operatorname{SEM}(\mathrm{n}=12)$.

2) $1543 \mathrm{FM}=$ Fermented milk with $S$. thermophilus TMC 1543.

Asterisks are significantly different from control $(* \mathrm{p}<0.05, * * \mathbf{P}<0.01)$.

concentration of the HMF group was significantly lower than that of the control group $(\mathrm{P}<0.05)$, and that of the LMF group showed a much lower level $(\mathrm{P}<0.01)$. The serum phospholipid concentrations for both the LMF group and the HMF group were significantly lower than those of control group $(\mathrm{P}<0.05)$. However, the serum HDL-cholesterol concentration was not statistically significant between the control group and the other four groups.

\section{Animal experiment 3}

Table 7 shows the food intake, body weight, serum lipids and liver lipids in rats. There were no significant differences in food intake between the control group and the 1543 FM group. The serum total cholesterol and phospholipid concentrations of the 1543 FM group were significantly lower than those of the control group $(\mathrm{P}<0.05)$. However, the serum triglyceride concentration and HDL-cholesterol concentration did not show any statistical significance be- tween the control group and the 1543 FM group. The liver triglyceride and cholesterol concentrations of the 1543 FM group did not show statistical significance between the control group and the $1543 \mathrm{FM}$ group ( $\mathbf{P}<0.05)$. Fecal steroid analyses were shown as total amounts of fecal steroids during 14 days. The amounts of excretion of both total bile acid and neutral sterol in feces of $1543 \mathrm{FM}$ group increased significantly in comparison with the control group $(\mathbf{P}<0.05)$.

\section{Discussion}

It was observed that fermented milk with $S$. thermophilus TMC 1543 containing whey protein concentrate (WPC) decreased the serum cholesterol level in rats more than the pasteurized milk base containing WPC (unpublished data). This result suggested that fermented milk with $S$. thermophilus TMC 1543 (1543 FM) may have cholesterol-lowering activity. It was 


\section{KAWASE, HASHIMOTO, HOSODA, MORITA and HOSONO}

found that $1543 \mathrm{FM}$ had serum cholesterol lowering activity in the present animal experiments. It is suggested that one of mechanisms behind serum cholesterol lowering action of this fermented milk was the inhibited absorption of bile acid and neutral steroid in the intestine, because the excretion of bile acid, neutral steroid and coprostanol through the feces significantly increased. All feces during experimental period were collected, because the analysis of the steroid in feces was important for the elucidation of the mechanism of serum cholesterol lowering activity. It has been known that inhibiting the absorption of bile acid in the intestine promotes the dissimulation from cholesterol to bile acid, which results in a decrease of serum cholesterol level ${ }^{19 !}$. And, absorption of cholesterol in the intestine also may have been inhibited by feeding $1543 \mathrm{FM}$, because it has been known that coprostanol is produced from cholesterol by intestinal bacteria ${ }^{13,211}$. Suzuki et al. ${ }^{26)}$ also reported that milk fermented by Lactobacillus acidophilus SBT 2056 inhibited the increase of serum cholesterol level in rats fed high cholesterol diets and resulted in the increase of bile acid and cholesterol in feces.

It was speculated that there were not only one but also several cholesterol lowering factors in $1543 \mathrm{FM}$ as the results in the present study. However, it was thought that special cholesterol lowering factors of 1543 FM existed except for the lactic acid, because there was no serum cholesterol lowering activity in fermented milk with $L$. casei TMC 109, despite that the acidity of $L$. case $i$ TMC 109 was higher than that of $S$. thermophilus TMC 1543.

The serum cholesterol lowering activities of fractions isolated from $1543 \mathrm{FM}$ were examined. HMF was hydrolyzed with a protease, because it has been already recognized that whey protein has a high serum cholesterol lowering action in rats ${ }^{15,16)}$. There was a statistically significant serum cholesterol lowering activity in only $\mathbf{L M F}$ in these fractions $(P<0.05)$. It is considered that there are peptides, amino acids, sugars, organic acids, and so on in LMF. In the future, it is necessary to clarify in which component of LMF the activity exists. Zommara et al. ${ }^{30)}$ reported that whey from cultured skim milk with $S$. thermo- philus decreased the serum cholesterol level in rats, whereas cultured skim milks with $L$. acidophilus or Bifidobacterium longum had no effect. Cholesterol lowering factors, which Rao et al. ${ }^{20}$ suggested, may exist in whey from fermented milk with $S$. thermophilus. Nakajima et al. ${ }^{17,18)}$ reported that slime materials containing polysaccharide produced by Lactococcus lactis subsp. cremoris SBT 0495 has serum cholesterol lowering effect in rats. S. thermophilus TMC 1543 was selected on the grounds that it produces fermented milk with a high viscosity. Highmolecular-weight function (HMF), which probably contains polysaccharides tended to lower serum cholesterol level in the present animal study, but the decrease was not statistically significant $(\mathrm{P}=0.08)$. Unlike our prediction, the serum cholesterol level of casein fraction was almost the same as that of whey fraction. Casein fraction may have cholesterol lowering activity, because casein fraction contains cells of S. thermophilus TMC 1543, denatured whey protein, and casein protein. Hashimoto et al. ${ }^{7}$ reported that freeze-dried cells of lactobacilli decreased the serum cholesterol levels in rats fed high cholesterol diet, and the amounts of bile acid in feces increased. There may be some insoluble peptides from milk protein produced by protease of $S$. thermophilus TMC 1543 in 1543 FM. Sugano et al. ${ }^{24,25}$ ) reported that the hydrophobic peptide of soybean protein prepared after exhaustive digestion by microbial proteases, which bound conjugated bile salt, decreased the serum cholesterol level in rats. Nagaoka ${ }^{16)}$ reported that the micellar solubility of cholesterol was decreased by $\beta$-lactoglobulin tryptic hydrolysate compared with casein tryptic hydrolysate. It is necessary to investigate the soluble and insoluble peptides in 1543 FM.

Gilliland and Speck $^{(6)}$ and Usman and Hosono ${ }^{27)}$ reported the deconjugation of bile acids by Lactobacillus spp. The deconjugation of bile acids trigger reduction of serum cholesterol level because free bile acids resulting from the deconjugation are excreted more rapidly than conjugated bile acids ${ }^{4)}$. However, S. thermophilus TMC 1543 is no resistant to gastric acid and bile acid, so that, deconjugating activity may not be one of the mechanisms behind the serum cholesterol lowering activity. Some reports ${ }^{3,10,28)}$ 
described the binding of cholesterol with lactic acid bacterial cells. Moreover, Usman and Hosono ${ }^{29)}$ reported the binding of cholesterol to the peptidoglycan of Lactobacillus gasseri. Hashimoto et $a l^{81}$ reported the effect of lactobacilli on bile acid, showing that lactobacilli had the binding ability of bile acid even in the dead condition. S. thermophilus TMC 1543 killed by gastric acid and bile acid also may bind bile acid and induce to excrete the bile acid through feces.

It is concluded that the mechanisms behind serum cholesterol lowering activity of fermented milk with $S$. thermophilus TMC 1543 would be attributable to promotion of excretion of bile acid and neutral steroid, and one of the cholesterol lowering factor may be a low-molecular material in LMF. However, the data gathered in the present study does not suffice to clarify the cholesterol lowering factors, and further investigations involving purification of the factors are needed.

\section{Acknowledgments}

The authors thank the staff of our laboratory for their appropriate maintenance of rats.

\section{References}

1) Agerbæk M, Gerdes LU, Richelsen B. Hypocholesterolaemic effect of a new fermented milk product in healthy middle-aged men. European Journal of Clinical Nutrition, $49: 346-352.1995$.

2) Bazzarre TL, Wu SL, Yuhas JA. Total and HDLcholesterol concentrations following yogurt and calcium supplementation. Nutrition Reports International, $28:$ 1225-1232. 1983.

3) Bottazzi V, Zacconi C, Gonzaga E, Paladino M. Absorption of cholesterol by intestinal lactic acid bacteria. Annales de Microbiologie, 36 : 1-5. 1986.

4) Chikai, T, Nakao H, Uchida K. Deconjugation of bile acids by human intestinal bacteria implanted in germ free rats. Lipids, 22:669-671. 1987.

5) Danno $H$, Jincho $Y$, Budiyanto $S$, Furukawa $Y$, Kimura S. A simple enzymatic quantitative analysis of triglycerides in tissues. Journal of Nutrition Science and Vitaminology, $38: 517-521.1992$.

6) Gilliland SE, Speck ML. Deconjugation of bile acids by intestinal Lactobacilli. Applied and Environmental Microbiology, 33 : 15-18. 1977.

7) Hashimoto H, Yamazaki $\mathrm{K}$, He F, Kawase M,
Hosoda M, Hosono A. Hypocholesterolemic effects of Lactobacillus casei subsp. casei TMC 0409 strain observed in rats fed cholesterol contained diets. Animal Science Journal, 70 : 90-97. 1999.

8) Hashimoto H, Kawase M, Hosoda M, He F, Morita $\mathrm{H}$. Hosono A. Binding, deconjugation and oxidation of taurocholic acid with lactobacillus cells. Milchwissenschaft, $55: 316^{-319 .} 2000$.

9) Hepner G, Fried R, St Jeor S, Fusetti L, Morin R. Hypocholesterolemic effect of yoghurt and milk. The American Journal of Clinical Nutrition, $32: 19-24$. 1979.

10) Hosono A, Tono-oka T. Binding of cholesterol with lactic acid bacterial cells. Milchwissenschaft, 50: 556-560. 1995.

11) Kawase $M$, Hashimoto $H$, Hosoda M, Morita $H$, Hosono A. Effect of administration of fermented milk containing whey protein concentrate to rats and healthy men on serum lipids and blood pressure. Journal of Dairy Science, 83:255-263. 2000.

12) Kovacs MIP, Anderson WE, Ackman RG. A simple method for the determination of cholesterol and some plant sterols in fishery-based food products. Journal of Food Science, 44 : 1299-1305. 1979.

13) Macdonald IA., Bokkenheuser VD, Winter J, McLernon AM, Mosbach EH. Degradation of steroids in the human gut. Journal of Lipid Research, 24 : 675-700. 1983.

14) Mann GV, Spoerry A. Studies of a surfactant and cholesteremia in the Maasai. The American Journal of Clinical Nutrition, $27: 464-469.1974$.

15) Nagaoka S, Kanamaru $Y$, Kuzuya $Y$, Kojima $T$, Kuwata T. Comparative studies on the serum cholesterol lowering action of whey protein and soybean protein in rats. Bioscience, Biotechnology, and Biochemistry, 56:1484-1485. 1992.

16) Nagaoka S. Studies on regulation of cholesterol metabolism induced by dietary food constituents or xenobiotics. Journal of Japanese Society of Nutrition and Food Science, $49: 303-313.1996$.

17) Nakajima H, Shuuji T. A Novel Phosphopolysaccharide from Slime-Forming Lactococcus lactis subspecies cremoris SBT 0495. Journal of Dairy Science, $73: 1472-1477.1990$.

18) Nakajima H, Suzuki $Y$, Kaizu H, Hirota T. Cholesterol lowering activity of ropy fermented milk. Journal of Food Science, 57 : 1327-1329. 1992.

19) Nazir DJ, Horlick L, Kudchodkar BJ, Sodhi HS. Mechanisms of action of cholestyramine in the treatment of hypercholesterolemia. Circulation XLVI : 


\section{KAWASE, HASHIMOTO, HOSODA, MORITA and HOSONO}

95-102. 1972.

20) Rao DR, Chawan CB, Pulusani SR. Influence of milk and Thermophilus milk on plasma cholesterol levels and hepatic cholesterogenesis in rats. Journal of Food Science, $46: 1339-1341.1981$.

21) Sadzikowski MR, Sperry JF, Wilkins TD. Cholesterol - Reducing Bacterium from Human Feces. Applied and Environmental Micobiology, 34 : 355-362. 1977.

22) Sautier C, Doucet C, Flament C, Lemonnier D. Effects of soy protein and saponins on serum, tissue and feces steroids in rat. Atherosclerosis, $34: 233-$ 241. 1979.

23) Sautier C, Dieng $\mathbf{K}$, Flament $C$, Doucet $C$, Suquet JP, Lemonnier D. Effects of whey protein, casein, soya-bean and sunflower proteins on the serum, tissue and faecal steroids in rats. British Journal of Nutrition, $49: 313-319.1983$.

24) Sugano M, Yamada $Y$, Yoshida K, Hashimoto $Y$, Matsuo T, Kimoto M. The hypocholesterolemic action of the undigested fraction of soybean protein in rats. Atherosclerosis, $72: 115-122.1988$.

25) Sugano M, Goto S, Yamada $Y$, Yoshida K, Hashimoto Y, Matsuo T, Kimoto M. Cholesterollowering activity of various undigested fractions of soybean protein in rats. Journal of Nutrition, 120: 977-985. 1990.

26) Suzuki Y, Kaizu H, Yamauchi Y. Effect of cultured milk on serum cholesterol concentrations in rats which fed high-cholesterol diets. Animal Science and Technology, 62 : 565-571. 1991.

27) Usman, Hosono A. Bile tolerance, taurocholate deconjugation, and binding of cholesterol by Lactobacillus gaserri strains. Journal of Dairy Science, 82 : 243-248. 1999.

28) Usman, Hosono A. Viability of Lactobacillus gasseri and its cholesterol-binding and antimutagenic activities during subsequent refrigerated storage in nonfermented milk. Journal of Dairy Science, 82 : 2536-2542. 1999.

29) Usman, Hosono A. Binding of cholesterol to the cells and peptidoglycan of Lactobacillus gasseri. Milchwissenschaft, $54:$ 495-498. 1999.

30) Zommara M, Tachibana N, Sakono M, Suzuki Y, Oda $T$, Hashiba $H$, Imaizumi $K$. Whey from cultured skim milk decreases serum cholesterol and increases antioxidant enzymes in liver and red blood cells in rats. Nutrition Research. 16 : 293-302. 1996. 